\title{
Pengembangan LKS Dengan Pendekatan Saintifik Berbasis Discovery Learning pada Materi Asam Basa untuk Pembelajaran Kimia Kelas XI SMA/MA
}

\author{
Pobby Sepriandi, Ellizar ${ }^{*}$, Rahadian Zainul ${ }^{\# 3}$ \\ Program Studi Pendidikan Kimia, Jurusan Kimia FMIPA, \\ Universitas Negeri Padang, Indonesia \\ ${ }^{3}$ Divisi Kimia Fisika, Jurusan Kimia, FMIPA Universitas Negeri Padang \\ e-mail : non_jalius@yahoo.com
}

\begin{abstract}
A research has been done to develop student worksheet with scientific approach and discovery based learning in Acids and Bases topic to learn chemistry for grade XI senior high school and also to describe it's validity and practicallities. The research used Research and Development (R\&D) method. The model has been used is 4-D model, which consisted of defin , design, develop and disseminate. Instruments of this research is questionnaire which consisted of validation sheet and practically sheet. Validity sheet was given to 4 chemistry lecturers and 2 senior high school chemistry teachers while practicallities sheet was given to 3 chemistry teachers and 25 students from SMAN 12 Padang. Based on the research, student worksheet product has been developed with scientific approach and discovery based learning in Acids and Bases topic for grade XI senior High Schoo. The average value of validity is 0,92 which very high validity category while the average value of practicallities is 0,82 which very high practicallities category. Based on the data, it can be seen that the student worksheet on Acids and Bases topic with scientific approach and discovery based learning for grade $X$ senior high school has very high validity level and very high practicallities level.
\end{abstract}

Key words: Worksheet, Scientific Approach, Discovery Learning, Acids and Bases, 4-D Model

\section{PENDAHULUAN}

Pembelajaran pada kurikulum 2013 dianjurkan menggunakan pendekatan saintifik atau pendekatan berbasis proses keilmuan. Pendekatan saintifik itu sendiri adalah proses pembelajaran yang dirancang agar peserta didik aktif dalam mengkonstruksi konsep, hukum atau prinsip melalui tahap-tahap yang ada pada pendekatan saintifik. Pendekatan saintifik diharapkan memberikan pemahaman kepada peserta didik dalam mengenal dan memahami berbagai materi menggunakan pendekatan ilmiah. ${ }^{[4]}$.

Kimia sebagai ilmu pengetahuan meliputi fakta-fakta, konsep-konsep, dan prinsip-prinsip. Kimia sebagai proses meliputi keterampilan-keterampilan dan sikap-sikap yang dimiliki untuk memperoleh dan mengembangkan ilmu pengetahuan atau ilmu kimia. Ilmu kimia adalah ilmu yang berlandaskan eksperimen (praktikum), artinya bahwa tidak mungkin belajar kimia tanpa laboratorium. Dengan melakukan percoban di laboratorium sesuai dengan instruksi dapat membantu peserta didik dalam memahami konsepkonsep kimia.

Salah satu topik kimia yang dapat dilakukan percobaan untuk membantu peserta didik dalam menemukan dan memahami konsep kimia yaitu asam basa. Pada topik asam basa peserta didik dituntut untuk dapat mendeskripsikan teori- teori asam basa dengan menentukan sifat dari suatu larutan dan menentukan $\mathrm{pH}$ suatu larutan dengap perhitungan.

Untuk dapat melakukan suatu eksperimen (praktikum) diperlukan suatu alat bantu berupa bahan ajar yang dapat menuntun peserta didik dalam menemukan konsep, salah satu bahan ajar yang dapat digunakan yaitu Lembar Kerja Siswa (LKS). Secara umum, LKS merupakan perangkat pembelajaran sebagai sarana pendukung pelaksanaan Rencana Pembelajaran (RP) ${ }^{[3]}$.

Dalam memperoleh bahan ajar sesuai dengan yeng diperlukan pada kurikulum 2013 yaitu dengah menggunakan pendekatan saintifik yang mana pendekatan saintifik harus digunakan oleh guru dalam penyampaian materi pada proses pembelajaran. Pendekatn saintifik memiliki beberap tahap yang harus dilakukan dalan pembelajaran yaitu, mengamati, menanya, mengumpulkap data, menalar/mengasosiasi dan menyimpulkan. Salah sat model pembeljaran yang dapat digunakan pada pendekatan seintifik yaitu model discovery learning. Menurut permendikbud ${ }^{[5]}$ langkah-langkah discivery learning dalan kegitan pembelajaran ada beberapa tahap yaitu stimulas, identifikasi masalah, pengumpulan data, pengolahan data, verifikasi, dan menarik kesimpulan.

Berdasarkan hasil-observasi-dan tanya jawab penulis dengan guru mata pelajaran kimia dan siswa di SMA N 12 Padang, SMA N 13 Padang, SMA N 1 Batang Kapas dan SMA N 2 Kerinci diperoleh informasi bahwa pembelajaran

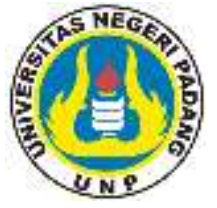


kimia di sekolah menggunakan LKS dari penerbit dan LKS yang dibuat oleh guru, khususnya pada materi asam basa untuk keles XI. LKS yang digunakan masih belum sesuai dengan kurikulum 2013, isi LKS belum menunjukan kepada pendekatan saintifik. LKS ini berisi uraian materi dan latihan-latihan tanpa menuntun siswa untuk menemukan konsep, sehingga siswa mudah lupa terhadap konsep yang dipelajari karena siswa tersebut tidak dilibatkan langsung dalam proses menemukan konsep dan terbiasa dengan menghafal.

Berdasarkan latar belakang, penulis berinisiatif melakukan penelitian untuk mengembangkan bahan ajar dalam bentuk Lembar Kerja Siswa dengan pendekatan saintifik berbasis discovery learning dengan judul "Pengembangan LKS dengan Pendekatan Saintifik Berbasis Discovery Learning pada Materi Asam Basa untuk Pembelajaran Kimia Kelas XI SMA/MA”.

\section{METODE PENELITIAN}

Jenis penelitian dalam penelitia ini adalah metode penalitian dan pengembangan atau Research and developmet $(R \& D)$. Menurut Sugiyono ${ }^{[8]}$ metode penelitian dan pengembangan digunakan untuk menghasilkan produk tertentu dan menguji keefektifan produk terebut. Penelitian dan pengembangan bahan ajar dalam bentuk LKS dengan pendekatan saintifik berbasis discovery learnng pada materi asam dan basa dilakuan di SMA Negeri 12 Padang semester genap tahun ajaran 2015/2016 sedangkan objek penelitian ini adalah bahan ajar dalam bentuk LKS dengan pendekatan saintifik berbasis discovery learning pada materi Asam Basa kelas XI SMA/MA.

Model pengembangan yang digunakan adalah model 4-D (Four D models). Model 4-D ini terdiri dari 4 tahap utama, yaitu: (1) pendefinisian (define), (2) perancangan (design), (3) pengembangan (develop) dan (4) penyebaran


beberapa tahap antara lain sebagai berikut. Pertama, Analisis awal-akhir bertujuan untuk memunculkan dan menetapkan masalah dasar yang dihadapi guru dan siswa dalam pembelajaran kimia. Berdasarkan jawaban dari pertanyaan yang diberikan dan observasi didapatkan bahwa bahan ajar yang digunakan disekolah berupa buku teks dan LKS dari penerbit dan dibuat oleh guru, materi yang disajikan dalam bahan ajar belum mampu menuntun siswa menemukan konsep dan belum tersedianya LKS pendekatan saintifik berbasis discovery learnng pada materi asam dan basa disekolah. Kedua. Analisis siswa bertujuan untuk mengidentifikasi target pembelajaran yaitu siswa. Identifikasi ini dilakukan untuk mengetahui karakteristik siswa, salah satunya perkembangan kognitif. Siswa kelas XI SMA mempunyai kisaran umur 16-18 tahun. Menurut teori belajar Piaget taraf berpikir anak usia tersebut pada tahapan perkembangan operasional (intelektual) yaitu anak sudah mampu berfikir logis, menarik kesimpulan dan menafsirkan.
Ketiga. Analisis tugas berupa analisis Kompetensi Inti (KI), Kompetensi Dasar (KD), dan indikator pada materi asam basa. Keempat, Analisis konsep dilakukan untuk mengidentifikasi konsep-konsep utama Konsep utama pada materi asam basa yaitu perbedaan asam basa menurut beberapa para ahli kimia, sifat suatu senyawa, penentuan sifat larutan asam dan basa menggunaakan kertas lakmus merah dan biru, penentuan sifat larutan asam dan basa menggunaakan kertas indikator universal, menetukan $\mathrm{pH}$ suatu larutan. Kelima, Analisis tujuan pembelajaran dirumuskan sebagai berikut.

1. Siswa dapat menjelaskan pengertian asam dan basa menurut Arrhenius, Bronsted-Lowry, dan Lewis.

2. Siswa dapat melakukan percobaan untuk mengidentifikasi berbagai larutan berdasarkan sifat larutan asam atau basa menggunakan kertas lakmus.

3. Siswa dapat menentukan $\mathrm{pH}$ dari suatu larutan dengan menggunakan indikator universal.

4. Siswa dapat menentukan $\mathrm{pH}$ dari suatu larutan secara perhitungan.

5. Siswa dapat melakukan titrasi asam basa berdasarkan prosedur kerja yang diberikan.

Pada tahap perancangan LKS dengan pendekatan saintifik berbasis discovery learning yang dikembangkan disesuaikan dengan tahap pembelajaran pendekatan saintifik dan model discovery learning, sistematika LKS dan format penulisan LKS dalam buku Panduan Pengembangan Bahap Ajar dari Depdiknas tahun $2008{ }^{[2]}$

Instrumen yang digunakan dalam menguji tingkat validitas adalah lembar validasi yang diisi oleh 6 orang validator (4 orang dosen Kimia Universitas Negeri Padang dan 2 orang guru kimia SMAN 12 Padang). Instrumen yang digunakan untuk menguji praktikalitas LKS dengan pendekatan saintifik berbasis discovery learning adalah lembar praktikalitas LKS asam basa dengan pendekatap saintifik berbasis discovery learning oleh guru kimia dan siswa. Validitas dan praktikalitas LKS dianalisis menggunakan moment kappa ${ }^{[1]}$.

$$
\text { moment kappa }(k)=\frac{P-P e}{1-P e}
$$

Keterangan:

$\mathrm{k} \quad=$ moment kappa

$\mathrm{P} \quad=$ Proporsi yang terealisasi, dihitung dengan cara jumlah nilai yang diberi oleh validator dibagi jumlah nilai maksimal

$\mathrm{Pe}=$ Proporsi yang tidak terealisasi, dihitung dengan cara jumlah nilai maksimal dikurangi jumlah nilai yang diberi oleh validator dibagi jumlah nilai maksimal. 
Tabel 1. Kategori Keputusan berdasarkan momen kappa (k)

\begin{tabular}{|c|c|}
\hline Interval & Kategori \\
\hline $\mathbf{0 . 8 1}-\mathbf{1 . 0 0}$ & Sangat tinggi \\
\hline $\mathbf{0 . 6 1}-\mathbf{0 . 8 0}$ & Tinggi \\
\hline $\mathbf{0 . 4 1}-\mathbf{0 . 6 0}$ & Sedang \\
\hline $\mathbf{0 . 2 1}-\mathbf{0 . 4 0}$ & Rendah \\
\hline $\mathbf{0 . 0 1}-\mathbf{0 . 2 0}$ & Sangat rendah \\
\hline$\leq \mathbf{0 . 0 0}$ & Tidak valid \\
\hline
\end{tabular}

\section{HASIL DAN PEMBAHASAN}

\section{A. Hasil Penelitian}

Berdasarkan tujuan dan prosedur penelitian telah dihasilkan suatu LKS dengan pendekatan saintifik berbasis discovery learning pada materi asam basa untuk pembelajaran kimia kelas XI SMA/MA. Pada penelitian ini peneliti menggunakan model pengembangan 4-D. Model ini terdiri atas 4 tahap yaitu pendefinisian (define), perancangan (design), pengembangan (develop) dan penyebaran (disseminate). Hasil untuk masing-masing tahap diuraikan sebagai berikut.

1. Tahap Pendefenisian (define)

Pada tahap ini diperoleh data yaitu data analisis ujung depan, analisis siswa, analisis tugas, analisis konsep, dan analisis tujuan pembelajaran.

a) Analisis ujung depan (awal-akhir)

Pada analisis ini dilakukan wawancara diperoleh data bahwa sebagian besar siswa pada materi asam basa masih kesulitan mengingat reaksi asam basa, menentukan $\mathrm{pH}$ suatu larutan dan melakukan titrasi asam basa. Selain itu disekolah masih belum terdapat bahan ajar yang menggambarkan pendekatan saintifik, bahan ajar yang digunakan disekolah untuk materi asam basa yaitu buku teks, LKS dan powerpoint.

b) Analisis siswa

Berdasarkan wawancara yang telah dilakukan diperoleh data sebagai berikut

1. Siswa kurang aktif dalam kegiatan belajar mengajar.

2. Siswa dalam satu kelas bersifat homogen, didominasis oleh siswa dengan kemampuan menengah.

3. Siswa mudah lupa terhadap materi yang telah dajarkan karena siswa tersebut tidak dilibatkan dalam proses belajar mengajar yang menuntut siswa dapat menemukan konsep, siswa hanya terbiasa dengan menghafal saja.

4. Kurangnya minat siswa dalam membaca bahan ajar yang mereka miliki.

Dari hasil pengamatan dalam proses pembelajaran didapatkan bahwa siswa kelas XI rata-rata berumur 18 tahun. Menurut pigmen taraf berfikir anak usia 18 tahun pada tahap perkembangan operasional formal. Secara umum karekteristik pemikiran remaja pada umur 18 tahun mempunyai kemampuan berfikir secara abstrak, menalar dan menarik kesimpulan dari informasi yang tersedia ${ }^{[9]}$.

Siswa meskipun telah memiliki kemampuan untuk berpikir abstrak, mereka masih perlu mendapat pelajaran dari hasil eksplorasi dunia nyata. Terlihat bahwa siswa SMA lebih tertarik jika materi pelajaran disampaikan melalui ilustrasi yang dekat dengannya sehingga mereka dengan muda memahami konsep dari apa yang dipelajarinya. LKS yang dirancang oleh peneliti dibuat dengan gambar yang bewarna dan dekat dengan kehidupan.

c) Analisis tugas

Analisis tugas adalah kumpulan prosedural untuk menentukan isi dalam LKS yang akan dibuat. Analisi tugas dilakukan untuk mencari isi materi ajar dalam bentuk garis besar. Analisis tugas biasa dilakukan pada analisis Kompetensi Dasar (KD).

d) Analisis konsep

pada analisis konsep materi yang tela diidentifikasi disesuaikan dengan keterampilan yang harus dicapai siswa, selanjutnya dibuat konsep yang secara sistematis serta mengaitka konsep dengan konsep lain yang relevan. Konsep yang akan dipelajari yaitu asam dan basa.

e) Analisis tujuan pembelajaran

Adapun tujuan pembelajaran asan dan basa tersebut antara lain:

1. Siswa dapat menjelaskan pengertian asam dap basa menurut Arrhenius, Bronsted-Lowry, dan Lewis.

2. Siswa dapat melakukan percobaan untuk mengidentifikasi berbagai larutan berdasarkap sifat larutan asam atau basa menggunaka kertas lakmus.

3. Siswa dapat menentukan $\mathrm{pH}$ dari suatu larutap dengan menggunakan indikator universal.

4. Siswa dapat menentukan $\mathrm{pH}$ dari suatu larutan secara perhitungan.

5. Siswa dapat melakukan titrasi asam basa berdasarkan prosedur kerja yang diberikan

2. Tahap perancangan (design)

Berdasarkan hasil pada tahap pendefinisian, selanjutnya dilakukan tahap perancangan. Penyajian LKS diproses menggunakan Microsoft Word 2007 menggunakan jenis font Time New Roman, Andalus, forte,Cambria, Bernard MT Condensen. Background yang digunakan pada bagian cover berwarna biry, sedangkan bagian isi LKS menggunakan warna putih.

LKS Asam Basa telah disusun berdasarkan Buku Panduan Depdiknas tahun 2008 meliputi: (1) Halama depan (cover), (2) Judul/ Identitas, (3) petunjuk

\section{Artikel Skripsi, Pobby Sepriandi, 1205733/2012, PRODI PENDIDIKAN KIMIA, JURUSAN KIMIA FMIPA

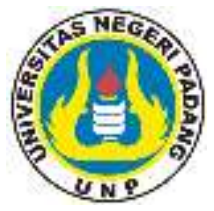


penggunaan LKS asam basa. (4) Kopetensi dasar yang akan dicapai siswa pada materi asam basa, (5) Materi asam basa berbasis discovery learning berisi enam kegiatan yaitu: stimulasi, identifikasi masalah dan hipotesis, pengumpulan data, pengolahan data, dan verifikasi, (6) Evaluasi (7) Daftar Pustaka..

3. Tahap pengembangan (develop)

Pada tahap pengembangan LKS dengan pendekatan santifik berbasis discovery learning pada materi asam basa diperoleh data hasil analisis uji Validitas dan praktikalitas.

a. Uji Validitas LKS

Uji Validitas LKS dilakukan oleh pakar dalam penelitian ini yaitu 4 orang dosen kimia FMIPA UNP dan 2 orang guru kimia SMA Negeri 12 Padang. Adapun hasil uji validitas dapat dilihat pada Tabel 2 berikut.

Table 2. Hasil Uji Validitas LKS

\begin{tabular}{|c|c|c|c|}
\hline $\begin{array}{c}\text { Aspek yang } \\
\text { Dinilai }\end{array}$ & $\begin{array}{c}\text { Jumlah } \\
\text { Skor }\end{array}$ & $\begin{array}{c}\text { Momen } \\
\text { Kappa }\end{array}$ & $\begin{array}{c}\text { Kategori } \\
\text { kevalidan }\end{array}$ \\
\hline $\begin{array}{c}\text { A. Komponen } \\
\text { Kelayakan } \\
\text { ssi }\end{array}$ & 224 & 0,93 & $\begin{array}{c}\text { Sangat } \\
\text { Tinggi }\end{array}$ \\
\hline $\begin{array}{c}\text { B. Komponen } \\
\text { Penyajian }\end{array}$ & 175 & 0,90 & $\begin{array}{c}\text { Sangat } \\
\text { Tinggi }\end{array}$ \\
\hline $\begin{array}{l}\text { C. Komponen } \\
\text { Kebahasaan }\end{array}$ & 135 & 0,93 & $\begin{array}{c}\text { Sangat } \\
\text { Tinggi }\end{array}$ \\
\hline $\begin{array}{l}\text { D. Komponen } \\
\text { Kegrafikan }\end{array}$ & 132 & 0,91 & $\begin{array}{c}\text { Sangat } \\
\text { Tinggi }\end{array}$ \\
\hline $\begin{array}{l}\text { Jumlah Skor } \\
\text { Total }\end{array}$ & $\mathbf{6 6 6}$ & & Sangat \\
\hline \multicolumn{2}{|c|}{ Momen kappa total } & $\mathbf{0 , 9 1}$ & Tinggi \\
\hline
\end{tabular}

b. Uji Praktikalitas LKS

Data praktikalitas LKS diperoleh dari pemberian angket kepada 3 orang guru kimia (angket respon guru) dan pemberian angket kepada 25 orang siswa (angket respon siswa) SMA Negeri 12 Padang. Adapun hasil uji praktikalitas dapat dilihat pada Tabel 3 dan Tabel 4 berikut.

Table 3. Hasil Uji Praktikalitas LKS oleh Guru

\begin{tabular}{|c|c|c|c|}
\hline $\begin{array}{c}\text { Aspek yang } \\
\text { Dinilai }\end{array}$ & $\begin{array}{c}\text { Jumlah } \\
\text { Skor }\end{array}$ & $\begin{array}{c}\text { Momen } \\
\text { Kappa }\end{array}$ & $\begin{array}{c}\text { Kategori } \\
\text { kevalidan }\end{array}$ \\
\hline $\begin{array}{c}\text { A. Komponen } \\
\text { Kemudahan } \\
\text { Penggunaan }\end{array}$ & 81 & 0,81 & $\begin{array}{c}\text { Sangat } \\
\text { Tinggi }\end{array}$ \\
\hline $\begin{array}{l}\text { B. Komponen } \\
\text { Efisiensi }\end{array}$ & 29 & 0,76 & Tinggi \\
\hline $\begin{array}{l}\text { Waktu } \\
\text { Pembelajaran }\end{array}$ & & & \\
\hline
\end{tabular}

\begin{tabular}{|l|c|c|c|}
\hline $\begin{array}{l}\text { C. Komponen } \\
\text { Manfaat }\end{array}$ & 69 & 0,78 & Tinggi \\
\hline $\begin{array}{l}\text { Jumlah Skor } \\
\text { Total }\end{array}$ & $\mathbf{1 7 9}$ & \multicolumn{2}{|}{} \\
\hline \multicolumn{2}{|l|}{ Momen kappa total } & $\mathbf{0 , 7 8}$ & Tinggi \\
\hline
\end{tabular}

Table 4. Hasil Uji Praktikalitas LKS oleh Siswa

\begin{tabular}{|c|c|c|c|}
\hline $\begin{array}{c}\text { Aspek yang } \\
\text { Dinilai }\end{array}$ & $\begin{array}{c}\text { Jumlah } \\
\text { Skor }\end{array}$ & $\begin{array}{c}\text { Momen } \\
\text { Kappa }\end{array}$ & $\begin{array}{c}\text { Kategori } \\
\text { kevalidan }\end{array}$ \\
\hline $\begin{array}{c}\text { A. Komponen } \\
\text { Kemudahan } \\
\text { Penggunaan }\end{array}$ & 325 & 0,86 & $\begin{array}{c}\text { Sangat } \\
\text { Tinggi }\end{array}$ \\
\hline $\begin{array}{c}\text { B. Komponen } \\
\text { Efisiensi } \\
\text { Waktu } \\
\text { Pembelajaran }\end{array}$ & 263 & 0,86 & $\begin{array}{c}\text { Sangat } \\
\text { Tinggi }\end{array}$ \\
\hline $\begin{array}{c}\text { Aspek yang } \\
\text { Dinilai }\end{array}$ & $\begin{array}{c}\text { Jumlah } \\
\text { Skor }\end{array}$ & $\begin{array}{c}\text { Momen } \\
\text { Kappa }\end{array}$ & $\begin{array}{c}\text { Kategori } \\
\text { kevalidan }\end{array}$ \\
\hline $\begin{array}{c}\text { C. Komponen } \\
\text { Manfaat }\end{array}$ & 432 & 0,84 & $\begin{array}{c}\text { Sangat } \\
\text { Tinggi }\end{array}$ \\
\hline $\begin{array}{l}\text { Jumlah Skor } \\
\text { Total }\end{array}$ & $\mathbf{1 0 4 7}$ & & \multicolumn{2}{|c|}{} \\
\hline \multicolumn{2}{|c|}{ Momen Kappa total } & $\mathbf{0 , 8 5}$ & Sangat \\
Tinggi
\end{tabular}

\section{B. Pembahasan}

Berdasarkan tujuan dan prosedur penelitian telah dihasilkan suatu LKS dengan pendektan saintifik berbasis discovery learning pada materi asam basa untuk pembelajaran kimia kelas XI SMA/MA, LK\$ tersebut dikembangkan berdasarkan LKS yang ada di sekolah. dimana LKS yang ada di sekolah tidak menggambarkan penedekatan saintifik sehingga dikembangkan dikembangkan LKS dengan pendekatan saintifik berbasis discovery learning pada materi asam basa untuk pembelajaran kimia kelas XI SMA/MA. Setelah dilakukan pengembangan maka dilakukan dua uji untuk mengetahuai kualitas dari LKS tersebut.

Pada lembar validasi berisi 30 aspek penilaian. Komponen penilaian terdiri dari komponen is komponen konstruksi (komponen penyajian) komponeh kebahasaan dan kegrafisan ${ }^{[2]}$.

1. Uji Validitas LKS dengan Pendekatan Saintifik Berbasis Discovery Learning pada Materi Asan Basa

Data validasi LKS dengan pendekatan saintifik berbasis discovery learning pada materi asam basa diperoleh dari 4 orang dosen kimia FMIPA UNP dan 2 orang guru kimia SMA Negeri 12 Padang. Daftar nama validator untk penilaiap pada lembar validasi LKS dengan pendekatah saintifik berbasis discovery learning pada materi

\section{Artikel Skripsi, Pobby Sepriandi, 1205733/2012,


asam basa dapat dilihat pada Tabel 5 sebagai berikut.

Tabel 5. Daftar Nama Validator LKS dengan Pendekatan Saintifik Berbasis Discovery Learning pada Materi Asam Basa

\begin{tabular}{|c|l|c|}
\hline No. & \multicolumn{1}{|c|}{ Nama Validator } & Jurusan/Spesialisasi \\
\hline 1. & Prof. Dr. Hj. Ellizar, M.Pd & Ilmu Kependidikan \\
\hline 2. & $\begin{array}{l}\text { Dr. Rahadian. Z, S.Pd, } \\
\text { M.Si }\end{array}$ & Kimia Fisika \\
\hline 3. & $\begin{array}{l}\text { Dra. Syamsi Aini, M.Si. } \\
\text { Ph.D }\end{array}$ & Kimia Anorganik \\
\hline 4. & Drs. Bahrizal, M.Si & Kimia Anorganik \\
\hline 5. & Rasmiati & $\begin{array}{l}\text { Guru Kimia SMA } \\
\text { Negeri 12 Padang }\end{array}$ \\
\hline 6. & Rahmida Yetti, S.Pd & $\begin{array}{l}\text { Guru Kimia SMA } \\
\text { Negeri 12 Padang }\end{array}$ \\
\hline
\end{tabular}

Berdasarkan lembar validitas dari keenam validator yang memberikan penilaian terhadap LKS yang dihasilkan dari segi kelayakan isi, kelayakan konstruksi (komponen penyajian), komponen kebahasaan dan komponen kegrafisan.

Penilaian Validitas LKS dengan pendekatan saintifik berbasis discovery learning pada materi asam basa ini didasarkan pada kategori validitas Boslaugh $^{[1]}$. Penilaian keenam validator terhadap komponen kelayakan isi LKS dengan pendekatan saintifik berbasis discovery learning pada materi asam basa memiliki rata-rata momen kappa sebesar 0,93 dengan kategori validitas sangat tinggi. Hal ini menunjukan bahwa materi dan konsep-konsep asam basa yang terdapat dalam LKS dengan pendekatan saintifik berbasis discovery learning pada materi asam basa sudah sesuai dengan Kompetensi Dasar, indikator, serta tujuan pembelajaran yang ingin dicapai, selain itu model yang disajikan dapat membimbing siswa dalam menemukan konsep dengan tingkat validitas sangat tinggi, hal ini sesuai dengan komponen kelayakan isi berdasarkan Depdiknas ${ }^{[2]}$.

Berdasarkan analisis validasi dari aspek penyajian LKS dengan pendekatan saintifik berbasis discovery learning pada materi asam basa memiliki rata-rata momen kappa dari keenam validator sebesar 0,90 dengan kategori validitas sangat tinggi. Hal ini menunjukan bahwa LKS dengan pendekatan saintifik berbasis discovery learning pada materi asam basa yang disusun sudah sistematis dan sesuai dengan pola pendekatan saintifik dan discovery learning dalam permendikbud $^{[4]}$. Pelaksanaan eksperimen yang dilakukan sudah sesuai dengan materi dan model-
Penilaian keenam validator berdasarkan aspek komponen kebahasaan LKS dengan pendekatan saintifik berbasis discovery learning pada materi asam basa menunjukan bahwa komponen kebahasaan yang terdapat pada LKS dengan pendekatan saintifik berbasis discovery learning pada materi asam basa memiliki rata-rata momen kappa sebesar 0,93 dengan kategori validasi sangat tinggi. Hal ini menujukan bahwa petunjuk dan informasi yang disampaikan dalam LKS dengan pendekatan saintifik berbasis discovery learning pada materi asam basa jelas bahasa yang digunakan sudah komunikatif, tida bermakna ganda, serta memenuhi kaidah bahasa Indonesia berdasarkan komponen kelayakan kebahasaan oleh Depdiknas ${ }^{[2]}$.

Penilaian keenam validator terhadap komponen kegrafisan penyajian LKS dengan pendekatan saintifik berbasis discovery learning pada materi asam basa memiliki rata-rata momen kappa sebesar 0,91 dengan kategori validasi sangat tinggi. Hal ini menunjukan bahwa secara keseluruhan komponen kegrafisan LKS dengap pendekatan saintifik berbasis discovery learning pada materi asam memiliki validitas yang sangat tinggi. Gambar pada model yang digunakan dapat diamati dengan jelas dan dapat menyampaikan informasi dari gambar tersebut secara efektif kepada siswa, hal ini sesuai dengan standar penilaian bahan ajar oleh badan sandar nasional pendidikan $^{[2,12]}$.

Walaupun secara keseluruhan penilaian komponen yang terdapat pada LKS dengan pendekatan saintifik berbasis discovery learning pada materi asam basa oleh validator meniliki kategori validasi sangat tinggi, namun masih ada beberapa komponen yang harus diperbaiki sesua saran yang diberikan oleh validator antaralaip sebagai berikut.

1. Memperbaiki penulisan reaksi asam basa Bronsted-Lowry agar lebih jelas yang di donorkan oleh asam adalah $\mathrm{H}^{+}$.

2. Memperjelas ilustrasi terutema pada submikroskopis.

3. Merubah warna kertas lakmus pada ilustrasi uji lkmus pada air sabun sehingga kertas lakmus menandakan sifat dari larutan tersebut benar.

4. Menambahkan konsentrasi larutan pada bahan yang digunakan pada percobaa penentuan sifat keasam suatu larutan.

5. Memperbaiki tampilan rumus penentuan pH suatu larutan dengan tidak memberikan rumus secara lansung tetapi siswa sendiri yang menemukan rumus tersebut.

\section{Artikel Skripsi, Pobby Sepriandi, 1205733/2012, PRODI PENDIDIKAN KIMIA, JURUSAN KIMIA FMIPA

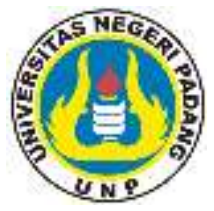


6. Menambah beberapa pertanyaan tentang penentuan $\mathrm{pH}$ suatu laruatan.

Sesuai dengan saran yang diberikan validator, maka dilakukan revisi terhadap LKS tersebut.

2. Uji Praktikalitas LKS dengan Pendekatan Saintifik Berbasis Discovery Learning pada Materi Asam Basa oleh Guru

Data analisis praktikalitas LKS dengan pendekatan saintifik berbasis discovery learning pada materi asam basa diperoleh dari 3 orang guru kimia SMA Negeri 12 Padang. Sehingga diperoleh momen kappa untuk mengungkapkan praktikalitas LKS dengan pendekatan saintifik berbasis discovery learning pada materi asam basa sebesar 0,78 denga ketegori prektikalitas tinggi.

Berarti LKS dengan pendekatan saintifik berbasis discovery learning pada materi asam basa yang dikembangkan memiliki praktikalitas tinggi. Penilaian praktiklitas LKS dengan pendekatan saintifik berbasis discovery learning pada materi asam basa ini didasarkan pada kategori praktikalitas Boslaugh $^{[1,11]}$.

Petunjuk penggunaan dan pengisian LKS dengan pendekatan saintifik berbasis discovery learning pada materi asam basa sudah dapat dipahami. LKS dengan pendekatan saintifik berbasis discovery learning pada materi asam basa yang dikembangkan sesuain dengan kompetensi dasar dan tujuan pembelajaran yang ingin dicapai. Model yang dgunakan pada LKS dengan pendekatan saintifik berbasis discovery learning pada materi asam basa sudah sesuai dangan tujuan yang ingin dicapai serta warna dan simbol yang terdapai pada model dapat menarik perhatian siswa.

3. Uji Praktikalitas LKS dengan Pendekatan Saintifik Berbasis Discovery Learning pada Materi Asam Basa oleh Siswa

Praktikalitas LKS dengan pendekatan saintifik berbasis discovery learning pada materi asam basa yang diperoleh dari angket respon siswa dan memiliki rata-rata momen kappa 0.85 dengan kategori praktikalitas sangat tinggi. Hal ini menunjukkan bahwa LKS dengan pendekatan saintifik berbasis discovery learning pada materi asam basa dapat membimbing siswa dalam menemukan dan memahami konsep asam basa dan praktis digunakan dalam pembelajaran, hal ini sesuai dengan pernyataan Mudjijo ${ }^{[10]}$ "Suatu bahan ajar dikatakan praktis apabila dapat dan mudah digunakan dan ditafsirkan".

IV. KESIMPULAN
Berdasarkan penelitian yang dilakukan, dihasilkan LKS dengan pendekatan saintifik berbasis discovery learning pada materi asam basa melalui penelitian pengembangan dengan menggunakan model pengembangan 4-D yang mempunyai kategori validitas dan praktikalitas sangat tinggi.

\section{UCAPAN TERIMAKASIH}

Penulis mengucapkan terimakasih kepada Ibu Prof. Dr. Hj.Ellizar, M.Pd, Bapak Dr. Rahadian.Z, S.Pd, M.Si, Ibu Dra. Syamsi Aini, M.Si, Ph.D, Bapak Drs. Zul Afkar, M.S dan Ibu Dr. Fajriah Azra, S.Pd, M.Si serta semua pihak yang telah membantu dalam penyelesaian penelitian dap penyusunan artikel ini.

\section{REFERENSI}

${ }^{[1]}$ Boslaugh, Sarah and Paul Andrew Watters. 2008 Statistics in a Nutshell, a desktop quick reference. Beijing, Cambridge, Famham, Köln, Sebastopo Taipei,Tokyo: O'reilly.

${ }^{[2]}$ Depdiknas.2008.Panduan Pengembangan Bahan Ajar. Departemen Pendidikan Nasional

${ }^{[3]}$ Hamdani. 2011. Strategi Belajar Mengajar. Bandung: Pustaka Setia.

${ }^{[4]}$ Hosnan, M. 2014. Pendekatan Saintifik dan Kontekstudl dalam Pembelajaran Abad 21. Bogor: Ghalia Indonesia.

${ }^{[5]}$ Permendikbud. 2013. Peraturan Menteri Pendidikan dan Kebudayaan Republik Indonesia Nomor 18A Tahup 2013 tentang Kurikulum 2013 Pedoman Umum Pembelajaran.

${ }^{[6]}$ Permendikbud. 2014. Peraturan Menteri Pendidikan dan Kebudayaan Republik Indonesia Nomor 59A Tahu 2014 tentang Kurikulum 2013 Sekolah Menengah Atas/ Madrasah Aliyah.

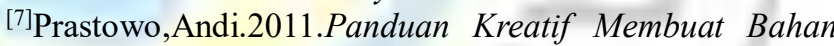
Ajar Inovatif. Jogjakarta: Diva Press.

${ }^{[8]}$ Sugiyono. 2011. Metode Penelitian Pendidikan, Pendekatan Kuantitatif, Kualitatif, dan R\&D. Bandung: Alfabeta

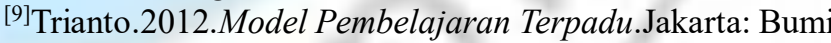
Aksara.

${ }^{[10]}$ Mudjijo. 1995. Tes Hasil Belajar. Jakarta : Bumi Aksara.

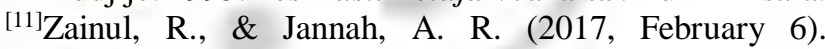
Pengembangan Media Pembelajaran Asam Basa Menggunakan Aplikasi Android Berbasis Chemistry Triangle Kelas XI SMA/MA. https://doi.org/10.31227/osf.io/muh8y

[12]Zainul, R. (2016, February 19). Disain, Metode-dan Penggunaan Software Pembelajaran Kimia Berbasis It Untuk Aktivitas Kelas dan Laboratorium Berbasis

\section{Artikel Skripsi, Pobby Sepriandi, 1205733/2012, PRODI PENDIDIKAN KIMIA, JURUSAN KIMIA FMIPA

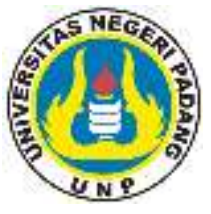


